\title{
Effectiveness of Online Marketing and Hedonism among University Students in Singapore
}

\author{
S. Aishwarya, M. Ayisha Millath
}

\begin{abstract}
Online marketing, also known as internet marketing, includes using interactive, virtual spaces to promote and sell products and services. Indeed, new synchronous, internet-based and mobile based communication techniques had helped restructure significant financial industries including marketing. Being cost-effective, flexible and quick and enjoying a global reach that is unprecedented, internet marketing has brought incredible benefits to various companies. This efficient, fresh technique, however, also includes its particular disadvantages, such as absence of personal contact, safety and privacy, etc. that should be taken into consideration. The present study concentrates on the effectiveness of Online marketing on purchasing behavior and hedonism among the students who are undergoing university studies. It reveals the interconnection between the purchasing behavior and hedonism among the students who came from different demographic factors and it shows the frequency of purchasing online and factors that lead to hedonism.
\end{abstract}

Keywords: Online marketing, Purchasing behavior, hedonism, university students, Internet.

\section{INTRODUCTION}

(Chaffy, 2000), merely describes the internet marketing as "the use of internet and associated digital techniques to attain marketing goals". This definition is a straight forward definition that does not affect the significant part of the client relationship. According to (Kotler, 2010), Online advertising consists of policies and operations aimed at promoting goods and services and building online customer relationships. (Burret, 2008) sees online marketing as closely targeting and interacting with customers while engaging with the most private, intimate medium ever invented. As these definitions of the relationship notion demonstrate online marketing revolve around communication and building customer relationships, a point that discriminates against traditional, offline marketing.

\section{METHODS OF ONLINE MARKETING}

Revised Manuscript Received on July 22, 2019.

S.Aishwarya, Alagappa Institute of Management, Alagappa University, Karaikudi, Sivaganaga dist. India. Email: aish.sudha@yahoo.com

Dr. M. Ayisha Millath, Alagappa Institute of Management, Alagappa University, Karaikudi, Sivaganga dist. India.

Email: ayishamillath05@gmail.com

\section{A. Online advertising}

Online advertising is the most widely recognized online marketing method. Virtual space is used in this technique to place marketing posts on websites in order to attract internet consumers. Just like offline marketing techniques and other kinds of online marketing, internet advertising's main goal is to boost revenues and boost brand awareness. Online marketing includes using the Internet to display promotional messages on computer screens (Duguay, 2012) and relates to "intentional messages posted on third-party websites, search engines and directories accessible through Internet access" (Ha, 2012)

\section{B. Online Marketing through email}

E-mail marketing, using e-mail to send promotional messages to internet users, was considered one of online marketing's most effective methods. Several researchers have highlighted the privileges of doing this online marketing (Read, 2010) (Jackson \& DeCormier,1999).In this respect, among its benefits, Peppers and Rodgers (2000) point to email marketing's "elevated reaction rates" and "low expenses" and think that these advantages "quickly turn email marketing into an invaluable tool" (Wreden, 1999).

\section{Social Media Marketing}

Social media has dramatically altered every aspect of our lives. In reality, it has become "the declaration technique in the twenty-first century, allowing us to express our beliefs, thoughts and ways in an entirely fresh way (Andrews, 2014). In addition to altering our way of living socially, social media offers unprecedented possibilities in the marketing globe and also has an enormous effect on corporations where they know that without a proper plan and social media strategy they have no opportunity to stand out in the quickly evolving digital freedom (Niall, 2000).In regard to social media pillars, it should be observed that social media is available in many forms such as blogs, micro blogs (Twitter), social networks (Facebook, Link), media sharing sites (YouTube, Flickr), social bookmarking and voting sites (Digg, Redit), review sites (Yelp), forums and virtual worlds (Second Life)

\section{Viral Marketing}

Another technique of undertaking online marketing that significantly overlaps with social media marketing is called viral marketing because of the centrality of "word of mouth. In reality, viral marketing is a type

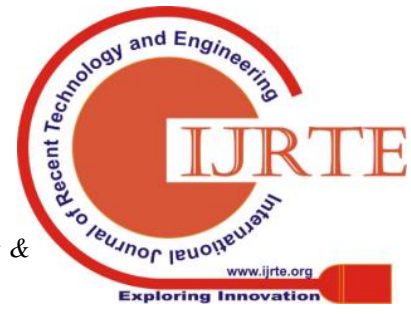


of mouth marketing that seeks to result in an exponentially spreading message (Strokes, 2009). It takes its name from a virus because of the similarities that marketers want to emulate, it is readily spread and the amount of individuals infected is increasing exponentially (Ferguson, 2008). Viral marketing operates by enabling individuals to communicate and send a marketing message and it is based on an elevated pass along form of an individual user to another user. It is evident that harnessing such a strong tool, word of mouth, and having others share and sell your products, even in comparison to launching a classic marketing campaign, ensures success.

\section{E. Search Engine Optimization}

Search Engine Optimization (SEO) is the method of enhancing website traffic quality and amount by enhancing the visibility of a website or web page to a web search engine user. SEO relates to improving unpaid outcomes known as natural outcomes and excludes payment placement purchases (Brown, 2009). SEO may target various search types, including image search, video search, academic search, news search, and vertical search engines specific to the industry.The significance of optimizing the search engine lies in the reality that clients use engines as a significant gateway to get around the internet most of the moment. To improve the rank of planned company pages in the search engine outcomes, some marketing methods have been created. SEO strategies aim to position a specified website among extremely listed entries returned by search engines, which in turn generates more traffic.

\section{HEDONISM}

Hedonism is a school of thought that claims that the main or most significant objectives of human existence are the pursuit of enjoyment and inherent products. A hedonist seeks to maximize net enjoyment that is pleasure minus pain and finally pleasure and happiness may stay stationary after lastly obtaining said enjoyment. This is a school of thought that says the pursuit of enjoyment is the most significant thing in life, which considers man to be driven by the desire for sensual pleasures - hence this quest for ' healthy life ' becomes man's driving force.The hedonistic consumer can be seen as an individual of love for enjoyment or self-indulgence with a high rate of consumption, more concerned with their own material objectives than with the broader perspective of culture.

\section{STATEMENT OF PROBLEM}

Even though online marketing is a powerful tool in marketing communications, still we need to consider some factors such as purchasing behavior and consumer satisfaction to retain the effectiveness of the same. The purchasing behavior of each individual varies in regarding to the product which he chooses. Also the hedonism lies on the satisfaction of customers on marketing and purchased product reveals the real success of the online marketing strategy. This study is conducted among the population where online shopping is more frequent to get a clear idea of their purchasing behavior according to the effectiveness of online marketing and level of hedonism.

\section{OBJECTIVES}

1. To have a detailed understanding on the concept of online marketing

2. To understand the demographic profile of the respondents 3. To identify the importance of the factors which leads to the effectiveness of online marketing

4. To identify the importance of the factors which leads to hedonism of the customers during online shopping

5. To analyze if there is a significant difference towards the effectiveness of online marketing aspects with respect to the demographic factors

6. To give suggestions for the betterment of online marketing

\section{RESEARCH METHODOLOGY}

The survey which was conducted in this study was completed and it includes a questionnaire that was asked to fill by the students in Singapore universities. Research Studies implementing students as respondents have been referred for detail process (M.AyishaMillath, S. Aishwarya and K.Malik Ali, 2017). In this study, the respondents were subjected to a 5 -point likert scale ( $1=$ strongly disagree, $5=$ strongly agree). Population is composed of students undergoing university courses in Singapore. The survey is conducted with the help of a questionnaire and it is distributed to the students. The research analysis tool, SPSS has been used to find the association of variables of online marketing and hedonism.

\section{SAMPLING METHODOLOGY}

A sample is a collection of units from a population used to determine truths about the population (Field, 2005). He also added that the bigger the sample size, most likely it represents the whole population. In this study, the population is indefinite and thus to make the sample more reflective and effective, the sample size of the study is determined as 399 according to Raosoft calculator. The data is collected using questionnaire as research instrument applying convenience sampling method.

\section{DATA ANALYSIS AND INTERPRETATION}

The data obtained from the questionnaire are thoroughly scrutinized before they analyzed using statistical tools. The quantity of the results obtained from the statistical technique and their subsequent interpretation depends to a degree on how well data were prepared and converted into a suitable form of analysis. The researcher provides the results of the descriptive statistics of the research data and it is divided into two parts. The first part consists of demographic profile of the respondents which gives the frequency and percentage that are demonstrated. The second part provides summary of mean and standard deviation values of the variables. Then the data collected have been analyzed with the help of ANOVA. After the tests carried out, the respective results were interpreted accordingly.

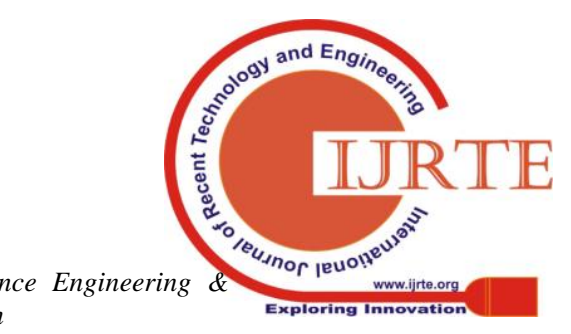




\section{DESCRIPTIVE ANALYSIS}

Table-I: Classification of the Respondents based on demographic variables

\begin{tabular}{|c|c|c|c|}
\hline $\begin{array}{c}\text { Demogra } \\
\text { phic } \\
\text { variables }\end{array}$ & Respective options & $\begin{array}{c}\text { Frequen } \\
\text { cy }\end{array}$ & Percent \\
\hline \multirow[t]{2}{*}{ Gender } & Male & 141 & 35.3 \\
\hline & Female & 258 & 64.7 \\
\hline \multirow[t]{3}{*}{ Age } & 20 to 30 Years & 246 & 61.7 \\
\hline & 31 to 40 Years & 127 & 31.8 \\
\hline & Above 40 Years & 26 & 6.5 \\
\hline \multirow{2}{*}{$\begin{array}{l}\text { Marital } \\
\text { status }\end{array}$} & Married & 56 & 14 \\
\hline & Unmarried & 343 & 86 \\
\hline \multirow{4}{*}{$\begin{array}{l}\text { Educatio } \\
\text { nal } \\
\text { qualifica } \\
\text { tion }\end{array}$} & UG & 222 & 55.6 \\
\hline & PG & 107 & 26.8 \\
\hline & Doctoral & 20 & 5.0 \\
\hline & Others & 50 & 12.5 \\
\hline \multirow{4}{*}{$\begin{array}{l}\text { Departm } \\
\text { ent }\end{array}$} & Arts and Science & 56 & 14.0 \\
\hline & Engineering & 168 & 42.1 \\
\hline & Management & 91 & 22.8 \\
\hline & Others & 84 & 21.1 \\
\hline \multirow{2}{*}{$\begin{array}{l}\text { Monthly } \\
\text { househol } \\
\text { d Income }\end{array}$} & Below SG $\$ 10000$ & 120 & 30.1 \\
\hline & SG $\$ 10000$ to 15000 & 279 & 69.9 \\
\hline \multirow[t]{3}{*}{ Ethnicity } & Chinese & 131 & 32.8 \\
\hline & Indian & 131 & 32.8 \\
\hline & Malaysian & 137 & 34.3 \\
\hline \multirow{3}{*}{$\begin{array}{l}\text { Total } \\
\text { number } \\
\text { of family } \\
\text { members }\end{array}$} & 3 & 73 & 18.3 \\
\hline & 4 & 209 & 52.4 \\
\hline & Above 4 & 117 & 29.3 \\
\hline \multirow{4}{*}{$\begin{array}{l}\text { Working } \\
\text { status of } \\
\text { parents/s } \\
\text { pouse }\end{array}$} & Father & 72 & 18 \\
\hline & Mother & 29 & 7.3 \\
\hline & Both & 242 & 60.7 \\
\hline & Spouse & 56 & 14 \\
\hline \multirow{4}{*}{$\begin{array}{l}\text { Frequenc } \\
\text { y of } \\
\text { online } \\
\text { shopping }\end{array}$} & Frequently (once in ten days) & 7 & 1.8 \\
\hline & $\begin{array}{l}\text { Occasionally (Once in a } \\
\text { month) }\end{array}$ & 165 & 41.4 \\
\hline & Rarely (Once in three months) & 133 & 33.3 \\
\hline & Very Rarely (Once in a Year) & 94 & 23.6 \\
\hline
\end{tabular}

Out of 399 students, 35.3 percent of the respondents were male and the remaining 64.7 percent were female. Thus the sample is female dominated. The age distribution of the respondents can be revealed from the table that 61.7 percent of the respondents belongs to the age group of 20 to 30 years, whereas the next group between 31 to 40 years which is 31.8 percent of the respondents. 26 percent of the respondents belong to the age group of above 40 years. It is found that 14 percent of the respondents are married and the remaining 86 percent are unmarried. Among the selected respondents, a majority of 55.6 percent is undergoing UG courses and 26.8 percent are studying PG courses. A percent of 5, are undergoing research studies and remaining 12.5 are doing other general courses. According to the department of studies, 14 percent are students from arts and science department and 42.1 percent from engineering department. It is further found that 22.8 percent from management and remaining 21.1 belongs to other general departments. We can conclude that 30 percent of the students are from the family who earn below SG\$ 10000 and 70 percent are from the family who are earning SG\$ 10000 to 15000.32 .8 percent of respondents belong to Chinese, 32.8 percent of respondents belong to Indians and 34.3 percent of respondents belong to Malaysian ethnicity. Thus this reveals the sample taken is approximately equally distributed among ethnicity. We understand that 18.3 percent of the respondent's family size consists of 3 members, 52.4 percent of the respondent's family size consists of 4 members and remaining 29.3 percent of the respondent's family size is above 4 members. Working status of the parents reveals that only Father is working in 22.6 percent respondent's family, Mother is working in 8.3 percent respondent's family and both parents are working in remaining 69.2 percent respondent's family. According to the frequency of online shopping, 1.8 percent of the respondents shop online frequently that is once in ten days. 41.4 percent of respondents shop online once in a month, 33.3 percent of the respondents undergo online shopping once in three months and 23.6 percent of the respondents shop online very rarely that is once in a year.

\section{X.RELIABILITY ANALYSIS}

Table-II: Case processing summary from the Reliability analysis

\begin{tabular}{|l|c|c|}
\hline Cases & N & Percentage \\
\hline Valid & 399 & 100.0 \\
\hline Excluded & 0 & .0 \\
\hline Total & 399 & 100.0 \\
\hline
\end{tabular}

The above table refers that there are 399 total valid samples and therefore nothing excluded.

\begin{tabular}{|l|c|c|}
\hline Factors & $\begin{array}{c}\text { Number of } \\
\text { items }\end{array}$ & $\begin{array}{c}\text { Cronbach's } \\
\text { Alpha value }\end{array}$ \\
\hline $\begin{array}{l}\text { Effectiveness of } \\
\text { online marketing }\end{array}$ & 15 & .859 \\
\hline $\begin{array}{l}\text { Hedonism among } \\
\text { university students }\end{array}$ & 15 & .912 \\
\hline
\end{tabular}

The calculated Cronbach's Alpha value for the items Effectiveness of online marketing is 0.859 and for hedonism among university students is 0.912 . Since the calculated value for both the constructs is greater than 0.7 (reliability coefficient of 0.7 or higher is considered acceptable in most social science research situations) that is a Cronbach's Alpha value $>0.7$, the items are considered as reliable. 


\section{MEAN RANKING ANALAYSIS}

A. Mean ranking analysis of factors that leads to the effectiveness of online marketing

Table-IV: Mean ranking analysis of factors that leads to the effectiveness of online marketing

\begin{tabular}{|c|c|c|}
\hline $\begin{array}{l}\text { Factors on effectiveness of Online } \\
\text { marketing }\end{array}$ & Mean & $\begin{array}{l}\text { Std. } \\
\text { Deviatio } \\
\text { n } \\
\end{array}$ \\
\hline The details provided in the website are clear & 4.43 & .535 \\
\hline $\begin{array}{l}\text { The website enables the user to acquire } \\
\text { required information }\end{array}$ & 4.43 & .641 \\
\hline $\begin{array}{l}\text { The website has related links to get maximum } \\
\text { information }\end{array}$ & 4.37 & .623 \\
\hline Choosing a product is easy and enjoyable & 4.50 & .626 \\
\hline Ordering Procedure is easy & 4.38 & .585 \\
\hline $\begin{array}{l}\text { Display of multimedia and graphics are } \\
\text { pleasing and inspire us to } \\
\text { order }\end{array}$ & 4.45 & .591 \\
\hline Process of payment is simple and easy & 4.33 & .668 \\
\hline $\begin{array}{l}\text { Pictures of the products gives a good display } \\
\text { of actual product }\end{array}$ & 4.42 & .557 \\
\hline $\begin{array}{l}\text { Additional details about size, weight and } \\
\text { colors are given clearly }\end{array}$ & 4.43 & .562 \\
\hline $\begin{array}{l}\text { The financial and personal information have } \\
\text { not been misused and } \\
\text { not results in data theft }\end{array}$ & 4.40 & .588 \\
\hline Secure electronic payment system & 4.42 & .578 \\
\hline $\begin{array}{l}\text { The site contains the details of customer } \\
\text { service and after sales } \\
\text { service }\end{array}$ & 4.40 & .562 \\
\hline $\begin{array}{l}\text { The website enables customers to send and } \\
\text { receive messages quickly }\end{array}$ & 4.53 & .629 \\
\hline The site enables to track the customer's order & 4.49 & .609 \\
\hline $\begin{array}{l}\text { Online support staff are responsible to the } \\
\text { calls of the customers }\end{array}$ & 4.49 & .763 \\
\hline
\end{tabular}

The above table highlights that the main factor of online marketing and to enable it effectively is the website should be easy to send and receive messages quickly which gets the score of 4.53. Choosing a product gets the next score of 4.50 . Keep tracking the orders and online support staff responsibility are getting equal scores of 4.49. Display of multimedia and graphics lays next to get a score of 4.45. The detail provided in the website and contains more information about the product and the additional information like size, weight and color gets the next score of 4.43. Secure electronic payment system and pictures of product matches the actual product during delivery gets the score of 4.42 . The financial and personal information's genuine responsibility without misuse and the customer service during sale and after sale gets equal score of 4.40. Easy ordering procedure gets the score of 4.38 and the related links provided gets the score of 4.37 . Finally, the process of payment gets the score of 4.33

\section{A. Mean ranking analysis of the factors that leads to}

Hedonism of Online Shopping customers
Table-V: Mean ranking analysis of factors that leads to Hedonism

\begin{tabular}{|c|c|c|}
\hline $\begin{array}{c}\text { Factors leads to Hedonism of Online shopping } \\
\text { customers }\end{array}$ & Mean & $\begin{array}{c}\text { Std. } \\
\text { Deviation }\end{array}$ \\
\hline There is no hidden charges during delivery & 4.42 & .782 \\
\hline Real product matches the displayed one & 4.52 & 609 \\
\hline Delivery on time as mentioned in website & 4.44 & .688 \\
\hline Refund policy is followed clearly & 4.33 & .824 \\
\hline Orders delivered in good condition & 4.34 & .663 \\
\hline Better product return service & 4.38 & .677 \\
\hline $\begin{array}{l}\text { Replacement of the product is possible if the } \\
\text { product is defective }\end{array}$ & 4.22 & .773 \\
\hline Product delivery is in good packing condition & 4.43 & .530 \\
\hline Cancellation of order is possible & 4.32 & .700 \\
\hline Customer service is good during product delivery & 4.53 & 608 \\
\hline The quality of the product meet my expectation & 4.41 & .677 \\
\hline $\begin{array}{l}\text { I found overall services of online services are } \\
\text { outstanding }\end{array}$ & 4.44 & .676 \\
\hline $\begin{array}{l}\text { I would recommend buying online to my friends and } \\
\text { relatives }\end{array}$ & 4.29 & .607 \\
\hline I would make repeated purchase through online & 4.39 & .728 \\
\hline $\begin{array}{l}\text { I am very much satisfied with online shopping } \\
\text { experience }\end{array}$ & 4.43 & .593 \\
\hline
\end{tabular}

From the above table, we conclude that the factor leading hedonism among the respondents is the customer service is good during delivery and that gets the highest score of 4.53 . From the respondents view, the next second place goes for the factor that the customer feels, real product matches the displayed one and its score is 4.52. Next score 4.44 goes to customer's acceptance of delivery on time as mentioned in website and the overall services of online shopping are outstanding. The respondents accept that they are very much satisfied with online shopping experience and they agree that the product delivery is in good packing condition with the score of 4.43. The respondent's next scoring of 4.41 is that they feel the quality of the product meet their expectation. They agree with the factor that they would make repeated purchase through online and its score is 4.39. The next rank goes to better product return service with the score of 4.38 . The respondents feel that the orders delivered in good condition with the score of 4.34. The next rank goes to the clear and good refund policy with the score of 4.33. Cancellation of order during online shopping is accepted with the score of 4.32. Recommendation of buying online to friends and relatives gets the score value of 4.29 . The respondents have given the score of 4.22 after they accept that the replacement of the product is possible if the product is defective. 


\section{ANALYSIS OF VARIANCE (ANOVA)}

A. Opinion of respondents with respect to gender regarding the effectiveness of online marketing
Null Hypothesis: There is no significant difference between the opinions regarding the effectiveness of online marketing with respect to the gender of the respondents.

Table-VI: Opinion of respondents with respect to gender regarding the effectiveness of online marketing

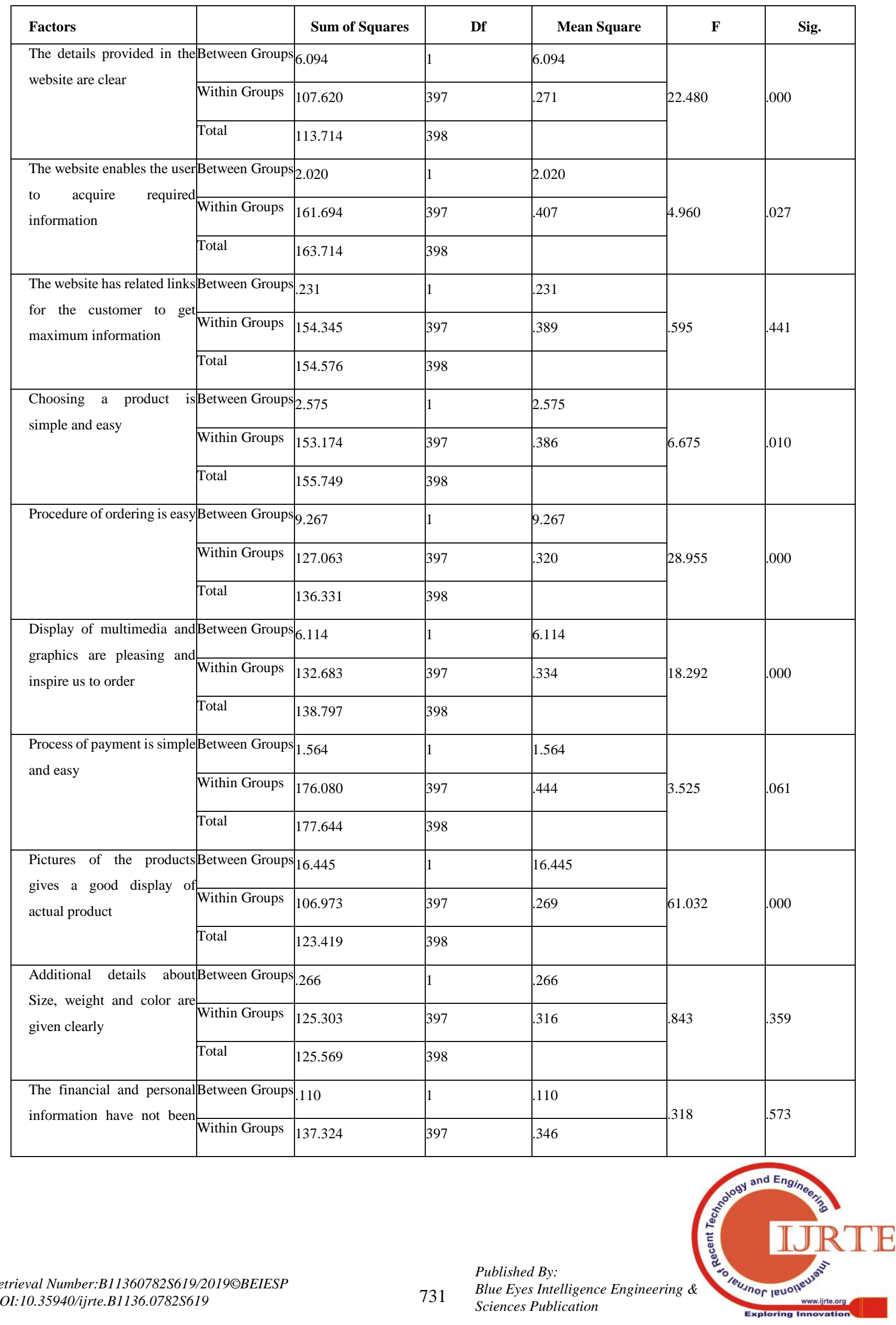


Effectiveness of Online Marketing and Hedonism among University Students in Singapore

\begin{tabular}{|c|c|c|c|c|c|c|}
\hline Factors & & Sum of Squares & Df & Mean Square & $\mathbf{F}$ & Sig. \\
\hline $\begin{array}{l}\text { misused and not results in } \\
\text { data theft }\end{array}$ & Total & 137.434 & 398 & & & \\
\hline \multirow{3}{*}{$\begin{array}{l}\text { Secure electronic payment } \\
\text { system }\end{array}$} & Between Group & 2.463 & 1 & 2.463 & \multirow{3}{*}{7.484} & \multirow{3}{*}{.007} \\
\hline & Within Groups & 130.640 & 397 & .329 & & \\
\hline & Total & 133.103 & 398 & & & \\
\hline \multirow{3}{*}{$\begin{array}{l}\text { The website contains the } \\
\text { details of customer service } \\
\text { and after sales service }\end{array}$} & Between Group & 52.319 & 1 & 2.319 & \multirow{3}{*}{7.454} & \multirow{3}{*}{.007} \\
\hline & Within Groups & 123.520 & 397 & .311 & & \\
\hline & Total & 125.840 & 398 & & & \\
\hline \multirow{3}{*}{$\begin{array}{l}\text { The website is able to send } \\
\text { and receive messages } \\
\text { quickly }\end{array}$} & Between Groups & 5.340 & 1 & .340 & \multirow{3}{*}{.858} & \multirow{3}{*}{355} \\
\hline & Within Groups & 157.079 & 397 & .396 & & \\
\hline & Total & 157.419 & 398 & & & \\
\hline \multirow{3}{*}{$\begin{array}{l}\text { The site enables customer to } \\
\text { check order and delivery } \\
\text { status of the products }\end{array}$} & Between Group & 3.325 & 1 & .325 & \multirow{3}{*}{.876} & \multirow{3}{*}{350} \\
\hline & Within Groups & 147.349 & 397 & .371 & & \\
\hline & Total & 147.674 & 398 & & & \\
\hline \multirow{3}{*}{$\begin{array}{l}\text { Online support staff are } \\
\text { responsive to the calls of } \\
\text { customers }\end{array}$} & Between Group & 5.471 & 1 & .471 & \multirow{3}{*}{.810} & \multirow{3}{*}{369} \\
\hline & Within Groups & 231.203 & 397 & .582 & & \\
\hline & Total & 231.674 & 398 & & & \\
\hline
\end{tabular}

Respondents are diverse in opinion towards the factors that leads to the effectiveness of online marketing with respect to gender. If ' $p$ ' value is less than 0.05 , the null hypothesis is rejected at 5 percent level of significance. The table gives result of highly insignificant values on the fact that the financial and personal information have not been misused and not results in data theft $(0.573)$, the website contains more related links to get more information (0.441), additional details about size, weight and colors are given clearly ( 0.359$)$, Online support staff are responsive to the calls of customers (0.369), sending and receiving messages quickly (0.355), Tracking the order status (0.350), the website enables the user to acquire required information ( 0.27$)$, easy and simple process of payment $(0.061)$, choosing a product is easy $(0.10)$, secure electronic payment system and the website contains customer service and after sales service (0.07) crossing over 0.05 which represents that the study failed to reject the null hypothesis. Hence it was

concluded that there is significant difference between gender and the opinion of respondents towards the factors in terms of the details provided in the website are clear, ordering procedure is easy, display of multimedia and graphics are pleasing and inspire the respondents to order and the pictures of the product gives a good display of actual product. Also there is no significant difference among the opinion of respondents towards the terms of the financial and personal information have not been misused and not results in data theft, the website contains more related links to get more information, additional details about size, weight and colors are given clearly, online support staff are responsive to the calls of customers, sending and receiving messages quickly, tracking the order status, enables the user to acquire required information, easy and simple process of payment, choosing a product is easy and secure electronic payment system and the website contains customer service and after sales service with respect to age.

Table-VII: ANOVA for significant difference between the opinions with respect to gender regarding the effectiveness of online marketing results.

\begin{tabular}{|l|c|c|c|c|}
\hline Factors on effectiveness of Online marketing & Mean & F & Sig. & $\begin{array}{c}\text { Null } \\
\text { Hypothesi } \\
\text { S }\end{array}$ \\
\hline The details provided in the website are clear & 0.271 & 22.480 & .000 & Rejected \\
\hline $\begin{array}{l}\text { The website enables the user to acquire required } \\
\text { information }\end{array}$ & 0.407 & 4.960 & .027 & Accepted \\
\hline $\begin{array}{l}\text { The website has related links to get maximum } \\
\text { information }\end{array}$ & 0.389 & 0.595 & .441 & Accepted \\
\hline Choosing a product is easy and enjoyable & 0.386 & 6.675 & .010 & Accepted \\
\hline Ordering Procedure is easy & 0.320 & 28.955 & .000 & Rejected \\
\hline $\begin{array}{l}\text { Display of multimedia and graphics are pleasing and } \\
\text { inspire us to order }\end{array}$ & 0.334 & 18.292 & .000 & Rejected \\
\hline Process of payment is simple and easy & 0.444 & 3.525 & .061 & Accepted \\
\hline
\end{tabular}




\begin{tabular}{|l|l|c|c|c|}
\hline Factors on effectiveness of Online marketing & Mean & F & Sig. & $\begin{array}{c}\text { Null } \\
\text { Hypothesi } \\
\text { S }\end{array}$ \\
\hline $\begin{array}{l}\text { Pictures of the products gives a good display of actual } \\
\text { product }\end{array}$ & 0.269 & 61.032 & .000 & Rejected \\
\hline $\begin{array}{l}\text { Additional details about size, weight and colors are } \\
\text { given } \\
\text { clearly }\end{array}$ & 0.316 & 0.843 & .359 & Accepted \\
\hline $\begin{array}{l}\text { The financial and personal information have not been } \\
\text { misused and not results in data theft }\end{array}$ & 0.346 & 0.318 & .573 & Accepted \\
\hline $\begin{array}{l}\text { Secure electronic payment system } \\
\text { The site contains the details of customer service and } \\
\text { after } \\
\text { sales service }\end{array}$ & 0.329 & 7.484 & .007 & Accepted \\
\hline $\begin{array}{l}\text { The website enables customers to send and receive } \\
\text { messages quickly }\end{array}$ & 0.396 & 0.858 & .355 & Accepted \\
\hline $\begin{array}{l}\text { The site enables to track the customer's order } \\
\text { Online support staff are responsible to the calls of the }\end{array}$ & 0.582 & 0.810 & .369 & Accepted \\
\hline customers & 0.876 & .350 & Accepted \\
\hline
\end{tabular}

\section{DISCUSSION}

1) From the descriptive statistics, major respondents are female and major percentage of age group is between 20 to 30 years. Ethnicity of the respondents is equally distributed. Major respondents are under graduate students and majority of the parents of respondents are both working. Approximately the frequency of online shopping is once in a month and once in three months among the respondents. Major percentage of the respondent's family members is 4 . The major percentage of respondents is from engineering background.

2) From the reliability test, both the factors of the effectiveness of online marketing and hedonism among the students are greater than the reliability coefficient and therefore the items are reliable.

3) From the mean ranking analysis, it is revealed that it is effective if the website is easy to send and receive messages quickly and this factor remains first rank on the whole. Choosing a product is easy, keep tracking the orders, online support staff responsibility are subsequently given successive ranks. Display of multimedia and graphics, details provided in the website contains more information about the product, additional details like size, weight and color of the product, secure electronic payment system, pictures of product matched the actual product during delivery, financial and personal information's genuine responsibility without misusing, customer service during sale and after sale, easy ordering procedure, related links provided and the process of payment gets the successive ranks

4) From the mean ranking analysis, it is also concluded that the first rank for the factor leading hedonism among the respondents is the customer service is good during delivery of the product. Real product matches the displayed one, customer's acceptance of delivery on time as mentioned in website, overall services of online shopping are outstanding, very much satisfied with the online shopping experience, product delivery is in good packing condition, they feel the quality of the product meet their expectation, repeated purchase through online, better product return service, orders delivered in good condition, clear and good refund policy, cancellation of order during online shopping, recommendation of buying online to friends and relatives and the replacement of the product if it is defective gets the successive ranks.

5) From the ANOVA test, the statement of null hypothesis is accepted in most of the factors and rejected in the factors like the ordering procedure is easy, display of multimedia and graphics are pleasing and inspire the respondents to order online, the details provided in the website are clear and the respondents view about the pictures of the product gives a good display of actual product with respect to gender.

\section{A.Implications}

Findings of the present study create a general opinion of the students to the effectiveness of online marketing and the purchasing behavior. The result of hedonism among the students also should insist the marketing team to make a new creative strategy by applying the highly motivated factors. Thus the implications can be done according to the importance of the factors that resulted in findings.

\section{B.Limitations}

The result should be considered with great care because samples are the students as respondents. In future to get a strong and perfect conclusion, the respondents from different background or general public should be taken. Future studies can be accompanied in qualitative basis to apply an in-depth analysis and to get an accurate result.

\section{CONCLUSION}

From the above study, it can be concluded that there is overall response and acceptance to the aspects of online shopping is due to the effectiveness of online marketing. The respondents accept the combination of various aspects of modern online marketing. Customers do require the online application which is used for online shopping to be more effective combined with all the factors. The marketing techniques can be effectively implied in online shopping applications so as to improve the shopping experience. This study further concluding the level of hedonism through online marketing is satisfied among the respondents. The main tool of marketing is to inspire customers to buy and the destination is the customer satisfaction. Thus this study started from the effectiveness of online marketing and ends with the acceptance of required hedonism among the respondents. Today's customers strongly accept and frequently doing online shopping because of their acceptance level of hedonism towards the products. Introducing major techniques and methods of online marketing, the rate of online shopping will definitely increase. 


\section{REFERENCES}

[1]. Andrews. (2014). Social Media Marketing: Internet Marketing Cheat Sheets. Volume 3, ebook Edition.

[2]. Brown. (2009). A complete guide to affiliate marketing on the web: how to use and profit from Affiliate marketing programs. Atlantic publishing group, Int.

[3]. Burret. (2008). MARKET ONLINE. B\&T MAGAZINE, 44-45.

[4]. Chaffey et al (2007). Top 10 emarkeitng strategies of today and tomorrow . Top 10 emarketing strategies.

[5]. Chaffy. (2000). Internet marketing strategy, implementation and pracitce. financial times prentice hall.

[6]. Duguay, A. (2012). Dimensions Of Source Credibility In The Case Of User-Generated Advertisements.

[7]. Ferguson. (2008). Discovering careers for your future. Computers, second edition. Ferguson Publishing Company.

[8]. Ha, L. (2012). online advertising research in advertising journals : A review. journal of current isssues \& research in advertising, 30: 31-48.

[9]. Kotler, P. e. (2010). Marketing for hospitality and tourism. New Jersey: Pearson prentice hall.

[10]. M.AyishaMillath, S.Aishwarya (Alagappa institute of management, Alagappa university), K.Malik Ali (2017). Desirable Features And Problems Encountered By Students of Distance Education Mode. International Journal of Current Advanced Research, 06(09), 5845-5850.

[11]. Niall. (2000). The email marketing dialogue. cambridge M.A: Forrester.

[12]. Read. (2010). impact of spam advertisement through email: a study to assess the influence of the anti-spam on the email marketing. Afr.J.Bus.Manage, 2362-2367.

[13]. Strokes. (2009). e-Marketing: The Essential Guide to Online Marketing. second editoin quirk emarketing pty ltd.

[14]. T, B. (2008). Market online. B \& T magazine, 58 (2682), 44-45.

[15]. Wreden. (1999). Mapping the frontiers on email marketing. harvard management communication letter. 